ABDIMAS: Jurnal Pengabdian Masyarakat Universitas Merdeka Malang
Vol.6(1) February 2021, 35-42
L-ISSN: 2721-138X e-ISSN: 2548-7159
Uttp://jurnal.unmer.ac.id/index.php/jpkm

\title{
Pelatihan Video Pembelajaran Kreatif di Era New Normal bagi Guru PAUD di Kecamatan Tanjung Bintang, Lampung Selatan
}

\author{
Laila Nursafitri, Elly Purwanti, Fitriyah \\ STAI Darussalam Lampung \\ Jl. Cendrawasih No.1 Labuhan Ratu I, Way Jepara, Lampung Timur, 34196, Indonesia
}

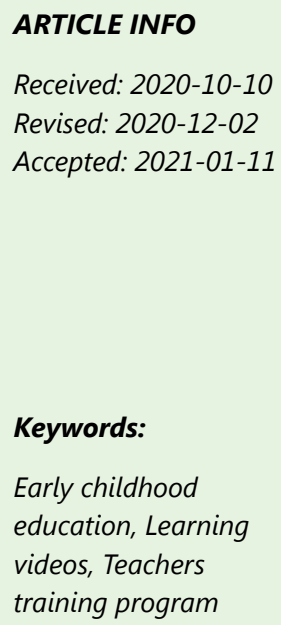

Received: 2020-10-10

Revised: 2020-12-02

Accepted: 2021-01-11

\section{Keywords:}

Early childhood education, Learning videos, Teachers training program

\begin{abstract}
Online learning was chosen as the main alternative in implementing learn from home during a pandemic There are many media that can be used in online learning such as learning videos. Learning videos are a medium for early childhood when they learn from home. Learning videos have components that make it easier for children to learn. Therefore, early childhood education (PAUD) teachers independently should be able to develop learning media. Thus, they can keep assisting students in learning both direct or long distance. This program aims to improve the skills of creative learning videos develop for PAUD teachers. This program collaborates with 3 institutions: PAUD Rumah Balita Pintar, TK Rumah Balita Pintar, and PAUD Setia Bunda in Tanjung Bintang. The program consists of introducing learning videos, training on video applications, and assisting in developing creative learning videos for early childhood. Hopefully with this activity PAUD teachers in Tanjung Bintang are able to developing creative learning videos for early childhood.
\end{abstract}

(C) 2021 Published by University of Merdeka Malang. This is an open access article distributed under the CC BY-SA 4.0 license

(https://creativecommons.org/licenses/by-sa/4.0/)

How to cite: Nursafitri, L., Purwanti, E., \& Fitriyah (2021). Pelatihan Video Pembelajaran Kreatif di Era New Normal bagi Guru PAUD di Kecamatan Tanjung Bintang, Lampung Selatan. Abdimas: Jurnal Pengabdian Masyarakat Universitas Merdeka Malang, 6(1), 35-42. https://doi.org/10.26905/abdimas.v6i1.4919

\section{PENDAHULUAN}

Wabah COVID-19 telah mempengaruhi hampir di seluruh sektor kehidupan manusia termasuk sektor pendidikan (Latip, 2020). Adanya kondisi yang mengharuskan menjaga jarak dalam melakukan interaksi sosial telah membawa perbedaan yang signifikan. Di dunia pendidikan, kebijakan SFH atau School from Home pun diterapkan untuk menekan penularan COVID-19 (Sudrajat, 2020). Pembelajaran yang selama ini dilaksanakan secara tatap muka dialihkan menjadi pembelajaran dari rumah atau learn from home. Hal ini sesuai dengan Surat Edaran Kementerian Pendidikan dan Kebudayaan Republik Indonesia Nomor 4 Tahun 2020 tentang Pelaksanaan Kebijakan Pendidikan dalam Masa Darurat Penyebaran Corona Virus Disease (COVID-19). 
ABDIMAS: Jurnal Pengabdian Masyarakat Universitas Merdeka Malang Volume 6, No. 1, February 2021: 35-42

Penutupan sekolah menjadi langkah mitigasi paling efektif untuk meminimalisir penyebaran wabah pada anak-anak (Herliandry et al., 2020). Learn from home menjadi kewajiban dalam pelaksanaan pembelajaran di setiap lembaga pendidikan termasuk lembaga Pendidikan Anak Usia Dini (PAUD). Di masa pandemi ini tantangan guru PAUD semakin bertambah karena harus memastikan peserta didik berkembang dari jarak jauh. Learn from home juga menjadi tantangan bagi orang tua dalam mendampingi anak belajar. Dibutuhkan kerjasama orang tua dan guru untuk membimbing siswa terutama masih berada di tingkat Taman Kanak-kanak (Sudrajat, 2020; Yuniriyanti et al., 2019).

Pendidikan Anak Usai Dini (PAUD) memiliki dunia unik yang berbeda dengan jenjang lainnya. Usia dini merupakan usia yang sangat rentan bagi perkembangan baik fisik maupun mental. Piaget menyebut tahap perkembangan anak usia 2-7 dengan istilah tahap preoperasional. Tahap ini merupakan tahap ketika anak-anak berpikir pada tingkat simbolis tetapi belum menggunakan operasi kognitif (Shaffer \& Kipp, 2014). Oleh sebab itu dibutuhkan objek-objek simbolis berupa media yang dapat digunakan sebagai perantara dalam belajar. Penggunaan media pembelajaran pada anak usia dini sangat berperan untuk memotivasi, merangsang, bereksplorasi dan bereksperimen (Mahyudin, 2020).

Salah satu media yang dapat dimanfaatkan saat learn from home untuk anak usia dini adalah video pembelajaran. Pembelajaran dengan menggunakan media video berkaitan dengan indera penglihatan dan pendengaran sehingga dapat mengefektifkan kemampuan alat indera anak (Fitria, 2018). Sebagai media pembelajaran video memiliki beberapa kelebihan diantaranya yaitu mudah digunakan dan mampu menjelaskan konten dengan lebih nyata (Batubara \& Ariani, 2016). Media video pembelajaran juga mempunyai hubungan dominan dalam meningkatkan prestasi belajar serta terbukti dapat meningkatkan keterampilan kognitif peserta didik (Khairani et al., 2019; Purnomo \& Wijayanto, 2018; Kurniawan \& Trisharsiwi, 2016). Video pembelajaran memiliki komponen-komponen yang dapat memudahkan anak untuk belajar.

Literasi teknologi informasi, dan komunikasi (TIK) menjadi faktor penting dalam pembelajaran jarak jauh selama masa pandemi COVID-19 (Latip, 2020). Namun kemampuan guru PAUD dalam penerapan teknologi informasi dan komunikasi (TIK) masih rendah (Pratiwi \& Nurhidayati, 2017). Begitu juga yang terjadi di lembaga PAUD Rumah Balita Pintar, TK Rumah Balita Pintar, dan PAUD Setia Bunda di Kecamatan Tanjung Bintang Lampung Selatan. Berdasarkan hasil observasi dan wawancara, guru belum mampu mengembangkan media video pembelajaran. Guru merasa kesulitan karena kurangnya pengetahuan dan juga pengembangan keterampilan tersebut. Selama ini guru melaksanakan pembelajaran hanya dengan instruksi melalui pesan yang dikirimkan ke orang tua siswa. Instruksi yang diberikan tak jarang membuat orang tua siswa kebingungan memahami cara melaksanakan instruksi tersebut. Selain itu siswa tidak termotivasi dengan maksimal.

Guru PAUD diharapkan memiliki keterampilan yang lebih lagi agar mampu mendampingi peserta didik dari jarak jauh, diantaranya keterampilan mengembangkan media video pembelajaran. Guru PAUD diharapkan memiliki keterampilan mengembangkan media pembelajaran secara mandiri. Hal ini agar guru mampu mendampingi peserta didik baik secara langsung maupun dari jarak jauh. Oleh sebab itu diperlukan kegiatan yang mampu meningkatkan keterampilan guru dalam mengembangkan media pembelajaran, dalam hal ini pengembangan media video pembelajaran. Hal inilah yang mendasari adanya kegiatan pelatihan mengembangkan media video pembelajaran kreatif untuk anak usia dini bagi guru PAUD. 
Kegiatan ini bertujuan untuk: (1) memecahkan masalah guru PAUD dalam mengembangkan media pembelajaran video yang kreatif untuk anak usia dini; dan (2) meningkatkan keterampilan guru PAUD dalam mengembangkan video pembelajaran yang kreatif untuk anak usia dini. Melalui kegiatan ini diharapkan: (1) dapat memecahkan masalah guru PAUD dalam mengembangkan media pembelajaran video yang kreatif untuk anak usia dini; dan (2) guru PAUD memiliki keterampilan mengembangkan video pembelajaran yang kreatif untuk anak usia dini.

\section{METODE}

Kegiatan ini berkolaborasi dengan 3 lembaga, yaitu PAUD Rumah Balita Pintar, TK Rumah Balita Pintar, dan PAUD Setia Bunda. Pelatihan dilaksanakan di Kec. Tanjung Bintang Lampung Selatan. Langkahlangkah kegiatan dalam program pengabdian masyarakat ini disajikan dalam gambar berikut:

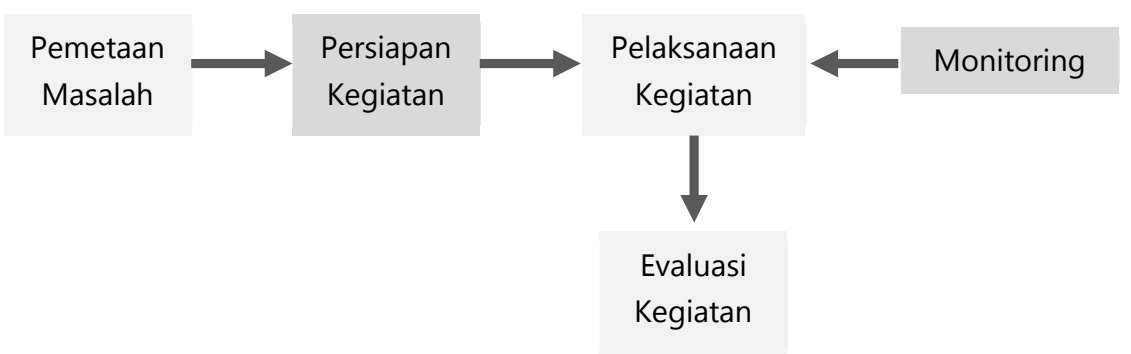

Gambar 1. Alur Kegiatan Pengabdian Masyarakat

Metode penyampaian dalam kegiatan ini dilakukan melalui presentasi dan praktik langsung. Kegiatan pelatihan terdiri dari: (1) kegiatan pengenalan konsep media video pembelajaran; (2) kegiatan pelatihan aplikasi media video; dan (3) kegiatan pendampingan pengembangan media video pembelajaran kreatif bagi anak usia dini.

\section{HASIL DAN PEMBAHASAN}

Kegiatan pengabdian masyarakat ini dilaksanakan di Desa Jati Indah Kecamatan Tanjung Bintang Kabupaten Lampung Selatan, Provinsi Lampung. Berikut ini gambaran lokasi program pengabdian masyarakat:
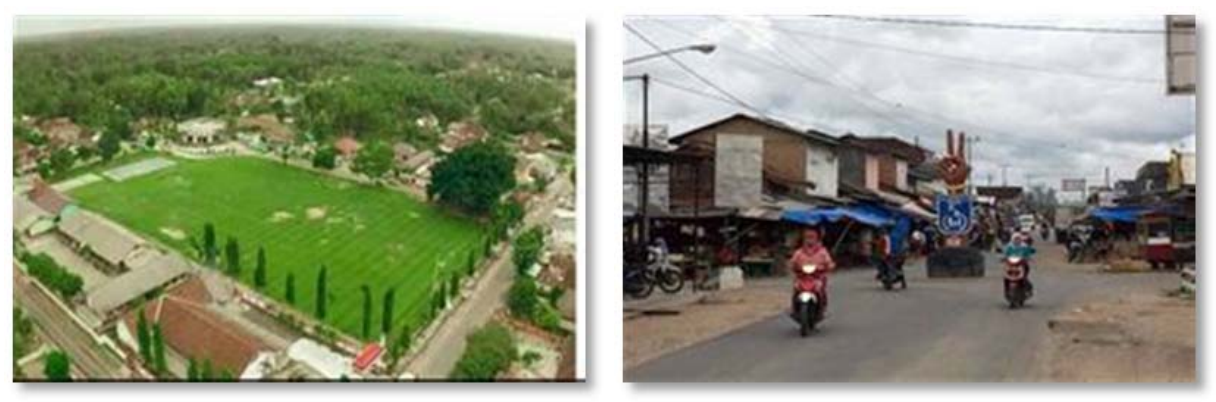

Gambar 2. Desa Jati Indah Kecamatan Tanjung Bintang Kabupaten Lampung Selatan, Provinsi Lampung 
ABDIMAS: Jurnal Pengabdian Masyarakat Universitas Merdeka Malang Volume 6, No. 1, February 2021: 35-42

Peserta yang terlibat berasal dari 3 lembaga, yaitu PAUD Rumah Balita Pintar, TK Rumah Balita Pintar, dan PAUD Setia Bunda. Kegiatan program pengabdian ini dilaksanakan di PAUD Rumah Balita Pintar. Berikut gambaran lokasi pelaksanaan kegiatan:
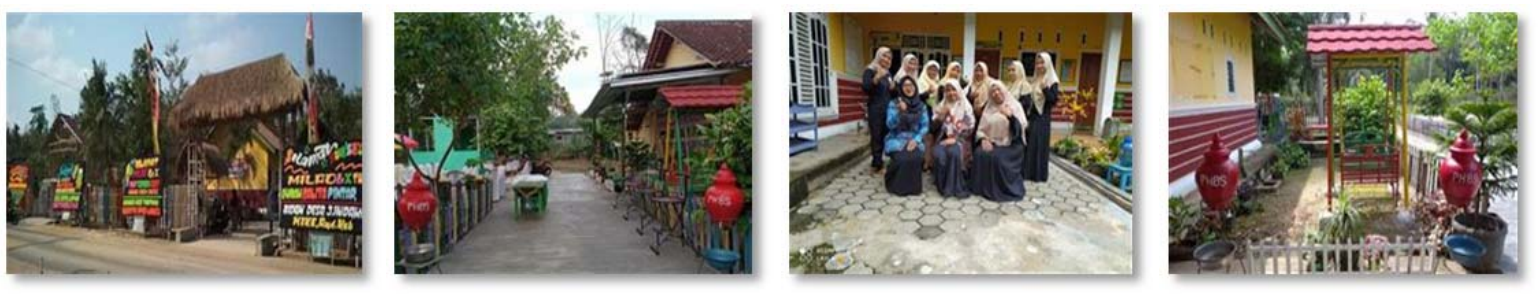

Gambar 3. Lokasi pelaksanaan kegiatan program pengabdian masyarakat

Berdasarkan langkah-langkah yang telah disajikan, hasil kegiatan pengabdian masyarakat ini adalah sebagai berikut.

\section{Pemetaan masalah}

Pemetaan masalah dilaksanaan setelah memperoleh data dari observasi dan wawancara. Observasi dilaksanakan terhadap proses pelaksanaan pembelajaran yang selama ini ditempuh di lembaga PAUD kec. Tanjung Bintang Lampung Selatan. Wawancara dilakukan kepada kepala sekolah PAUD untuk menggali masalah-masalah yang menjadi kegelisahan. Kemudian secara bersama-sama memetakan masalah yang mendesak untuk dipecahkan terlebih dahulu.

Berdasarkan hasil pemetaan diperoleh masalah yang menjadi prioritas dan mendesak untuk dipecahkan sesuai dengan kondisi saat ini, learn from home di masa pandemi, yaitu guru belum mampu mengembangkan media video pembelajaran danguru merasa kesulitan karena kurangnya pengetahuan dan juga pengembangan keterampilan tersebut. Selama ini guru melaksanakan pembelajaran dengan cara membagikan materi melalui foto dan dikirimkan kepada wali murid untuk dapat dikerjakan pada lembar kerja anak. Hal ini kurang efektif karena masih banyak orang tua yang merasa bingung dalam mendampingi belajar anak. Selanjutnya didapatkan kesepakatan bersama untuk membuat sebuah kegiatan dalam rangka meningkatkan keterampilan guru dalam mengembangkan video pembelajaran kreatif untuk anak usia dini.

\section{Persiapan kegiatan}

Setelah memetakan masalah, kegiatan selanjutnya melakukan persiapan kegiatan. Persiapan yang dilakukan yaitu: (1) mengidentifikasi keterampilan yang perlu dikuasai dalam pengembangan media video pembelajaran; (2) memilih dan menyusun sumber belajar yang relevan untuk melaksanakan pelatihan pengembangan media video pembelajaran; (3) menyusun langkah pelaksanaan kegiatan pelatihan. 


\section{Pelaksanaan kegiatan}

Kegiatan pelatihan dilaksanakan di Lembaga PAUD Terpadu Rumah Balita Pintar Tanjung Bintang, Lampung Selatan. Peserta pelatihan terdiri dari 10 orang guru PAUD dari 3 lembaga, yaitu PAUD Rumah Balita Pintar, TK Rumah Balita Pintar, dan PAUD Setia Bunda. Kegiatan dilaksanakan pada hari Jumat, 8 Agustus 2020 dari pukul 08.00 s.d selesai dengan tetap memperhatikan protokol kesehatan. Kegiatan yang dilaksanakan disajikan sebagai berikut:

\section{Pembukaan kegiatan}

Rangkaian kegiatan diawali dengan pembukaan (Gambar 4). Pembukaan dilakukan oleh kepala sekolah PAUD Rumah Balita Pintar, Setyaningsih, S.Pd.I. Dalam pembukaan ini kepala sekolah berharap agar guru PAUD memiliki peningkatan keterampilan yang mendukung pembelajaran di masa pandemi.

\section{Kegiatan pengenalan konsep media video pembelajaran}

Kegiatan berikutnya pendamping memberikan materi berupa pengenalan konsep media video pembelajaran (Gambar 5).
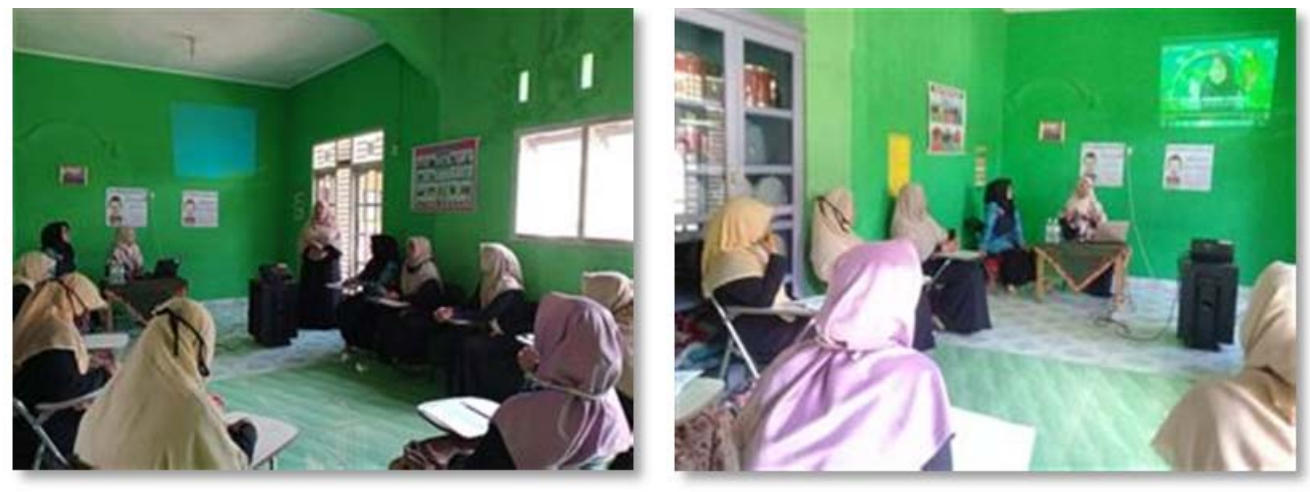

Gambar 4. Pembukaan kegiatan

Gambar 5. Pengenalan konsep media video pembelajaran

Peserta pelatihan memperhatikan pemaparan materi beserta contoh-contoh yang disajikan. Melalui pemberian materi ini diharapkan peserta dapat memperoleh gambaran media pembelajaran video yang menarik dan tepat bagi anak usia dini.

\section{Kegiatan pelatihan aplikasi media video}

Setelah menerima pengenalan materi media video pembelajaran, peserta mendapatkan pelatihan tentang aplikasi media video (Gambar 6).

Dalam kegiatan ini aplikasi yang diperkenalkan dan dipelajari yaitu aplikasi Kine Master. Aplikasi ini dipilih karena memiliki fitur-fitur yang mudah untuk digunakan oleh pemula. Dalam sesi ini peserta 
ABDIMAS: Jurnal Pengabdian Masyarakat Universitas Merdeka Malang Volume 6, No. 1, February 2021: 35-42

langsung berinteraksi dengan aplikasi Kine Master di gadget masing-masing sehingga peserta lebih mudah mengenali fitur-fitur yang ada pada aplikasi tersebut.

\section{Kegiatan pendampingan pengembangan media video pembelajaran kreatif bagi anak usia dini}

Kegiatan selanjutnya peserta melaksanakan praktik pengembangan media video (Gambar 7). Peserta mengambil video langsung, kemudian melakukan editing dengan aplikasi Kine Master.
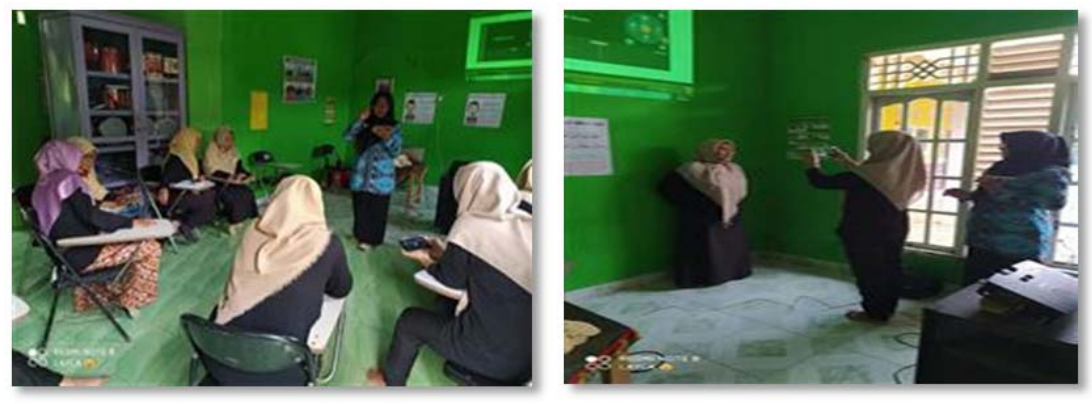

Gambar 6. Pelatihan aplikasi media video

Gambar 7. Pendampingan pengembangan media video pembelajaran

Peserta mendapatkan bimbingan dari para pendamping dari STAI Darussalam Lampung. Pendampingan ini bertujuan agar peserta mampu merancang dan mengembangkan media video yang sesuai untuk anak usia dini, seperti penggunaan warna background, pemilihan gambar/animasi, dan lain sebagainya.

\section{Monitoring Kegiatan}

Kegiatan monitoring dilakukan pada saat pelaksanaan kegiatan pelatihan guru PAUD dalam mengembangkan media video pembelajaran kreatif untuk anak usia dini. Berdasarkan hasil monitoring terlihat bahwa kegiatan ini mendapatkan antusias yang tinggi dari para peserta. Pada saat pemberian materi pengenalan konsep media video pembelajaran, peserta tampak antusias. Para peserta sangat tertarik dengan contoh-contoh video yang disajikan pemateri. Para peserta termotivasi untuk belajar mengembangkan sendiri media tersebut namun peserta juga kebingungan tentang cara mengembangkan media video pembelajaran yang menarik. Selanjutnya peserta diperkenalkan dengan sebuah aplikasi editing video, yaitu aplikasi Kine Master. Seluruh peserta kegiatan belum ada yang menggunakan aplikasi tersebut, bahkan cenderung baru mengenal pada saat kegiatan dilaksanakan. Sehingga para peserta harus mendownload terlebih dahulu di gadget masing-masing. Dengan kondisi tersebut maka waktu yang dibutuhkan pada sesi ini sedikit lebih lama dari rencana awal. Kemudian para peserta mempraktikkan langsung pengembangan media video pembelajaran, mulai dari memilih tema pembelajaran, pengambilan gambar, memilih gambar-gambar/animasi pendukung, memilih suara/ musik, melakukan editing video, sampai dengan finishing video menjadi format $\mathrm{mp} 4$. dan bisa dibagikan dengan perangkat lain. 


\section{Evaluasi Kegiatan}

Setelah kegiatan selesai dilaksanakan, pendamping dan peserta bersama-sama melakukan evaluasi kegiatan. Hasil evaluasi disusun dalam bentuk laporan tertulis. Berdasarkan proses evaluasi diperoleh beberapa catatan, sebagai berikut: (1) Peserta memiliki beberapa hambatan seperti handphone yang belum support dengan aplikasi, dan memori handphone yang terlalu penuh. Hal ini menghabiskan waktu yang lama untuk menyiapkannya; (2) Peserta belum siap dengan bahan untuk materi pembelajaran yang akan dibuat menjadi video, seperti gambar-gambar, animasi, dan lain sebagainya; dan (3) Kegiatan dilaksanakan terlalu singkat. Peserta membutuhkan waktu tambahan untuk bisa menggali kreativitas mereka.

\section{SIMPULAN DAN SARAN}

\section{Simpulan}

Kegiatan pelatihan pengembangan video kreatif untuk PAUD di lembaga PAUD Terpadu Rumah Balita Pintar Tanjung Bintang, Lampung Selatan berjalan dengan baik, tertib, aman, dan lancar. Terbukti dengan antusias para guru dalam proses pelatihan sampai dengan menghasilkan sebuah video. Keterampilan guru dalam membuat media pembelajaran menjadi faktor yang berpengaruh dalam keberhasilan pembelajaran di masa pandemi ini. Melalui kegiatan ini diharapkan guru PAUD akan memiliki keterampilan lebih dalam mengembangkan media pembelajaran secara mandiri.

\section{Saran}

Dibutuhkan komitmen bersama dari guru untuk terus mengeksplorasi keterampilan agar pembelajaran yang dilaksanakan lebih kreatif. Kegiatan pengabdian masyarakat ini sebaiknya dilaksanakan dalam beberapa sesi. Selain itu perlu diadakan pendampingan berkelanjutan agar kompetensi guru dalam mengembangkan media video dapat berkembang secara maksimal.

\section{DAFTAR PUSTAKA}

Batubara, H. H., \& Ariani, D. N. (2016). Pemanfaatan video sebagai media pembelajaran matematika SD/MI. Muallimuna: Jurnal Madrasah Ibtidaiyah, 2(1), 47. https://doi.org/10.31602/muallimuna.v2i1.741

Fitria, A. (2018). Penggunaan media audio visual dalam pembelajaran anak usia dini. Cakrawala Dini: Jurnal Pendidikan Anak Usia Dini, 5(2). https://doi.org/10.17509/cd.v5i2.10498

Herliandry, L. D., Nurhasanah, N., Suban, M. E., \& Kuswanto, H. (2020). Pembelajaran pada masa pandemi COVID-19. JTP - Jurnal Teknologi Pendidikan, 22(1), 65-70. https://doi.org/10.21009/jtp.v22i1.15286

Khairani, M., Sutisna, S., \& Suyanto, S. (2019). Studi meta-analisis pengaruh video pembelajaran terhadap hasil belajar peserta didik. Jurnal Biolokus: Jurnal Penelitian Pendidikan Biologi dan Biologi, 2(1), 158-166. http://dx.doi.org/10.30821/biolokus.v2i1.442 
ABDIMAS: Jurnal Pengabdian Masyarakat Universitas Merdeka Malang Volume 6, No. 1, February 2021: 35-42

Kurniawan, T. D., \& Trisharsiwi, T. (2016). Pengaruh penggunaan media video pembelajaran terhadap prestasi belajar Ilmu Pengetahuan Sosial siswa kelas V SD Se-Kecamatan Gedangsari Gunungkidul tahun ajaran 2015/2016. Trihayu, 3(1), 21-26.

Latip, A. (2020). Peran literasi teknologi informasi dan komunikasi pada pembelajaran jarak jauh di masa pandemi COVID-19. EduTeach: Jurnal Edukasi dan Teknologi Pembelajaran, 1(2), 108-116. https://doi.org/10.37859/eduteach.v1i2.1956

Mahyudin, M. (2020). Peran media pembelajaran guru Pendidikan Anak Usia Dini (PAUD) di Provinsi Jambi. Jurnal Ilmiah Universitas Batanghari Jambi, 20(1), 60.

https://doi.org/10.33087/jiubj.v20i1.869

Pratiwi, U., \& Nurhidayati, N. (2017). Penerapan Sains Teknologi Masyarakat (STM) untuk peningkatkan kemampuan pedagogik guru dan calon guru PAUD Kec. Panjer Kab. Kebumen. Journal of Dedicators Community, 1(1), 82-93. https://doi.org/10.34001/jdc.v1i1.441

Purnomo, E., \& Wijayanto, P. (2018). Efektivitas model pelatihan parenting autism berbasis media video. Jurnal Kwangsan, 6(1), 68. https://doi.org/10.31800/jkwangsan-jtp.v6n1.p68-79

Shaffer, D. R., \& Kipp, K. (2010). Developmental psychology: Childhood and adolescence $7^{\text {th }}$ Ed. Wadsworth/Cengage Learning.

Sudrajat, J. (2020). Kompetensi guru di masa pandemi COVID-19. Jurnal Riset Ekonomi dan Bisnis, 13(1), 100-110.

Yuniriyanti, E., Sudarwati, R., \& Subianto, T. (2019). PKM: PAUD PKK Al Ikhsan Desa Panggungrejo wujud sinergi desa dan pendidikan anak usia dini. Dharmakarya: Jurnal Aplikasi Ipteks untuk Masyarakat, 8(3), 210-215. https://doi.org/10.24198/dharmakarya.v8i3.22758 